\title{
In Silico Analysis of Pinostrobin Derivatives from Boesenbergia pandurata on ErbB4 Kinase Target and QSPR Linear Models to Predict Drug Clearance for Searching Anti-Breast Cancer Drug Candidates
}

\begin{abstract}
Ersanda Nurma Praditapuspa', Siswandono ${ }^{2, *}$, Tri Widiandani ${ }^{2}$
Ersanda Nurma Praditapuspa', Siswandono ${ }^{2, *}$, Tri Widiandani ${ }^{2}$

'Master Program of Pharmaceutical Sciences, Faculty of Pharmacy, Airlangga University, Surabaya, INDONESIA.

2Department of Pharmaceutical Chemistry, Faculty of Pharmacy, Airlangga Univer.

angga University, Surabaya, INDONESIA.

\section{Correspondence}

\section{Siswandono}

Department of Pharmaceutical Chemistry, Faculty of Pharmacy, Airlangga University, Surabaya 60155, INDONESIA.

Phone no/ Fax: (031) 5933150/(031) 5935249;

E-mail: prof.sis@ff.unair.ac.id

History

- Submission Date: 23-06-2021

ABSTRACT

Background: ErbB4 is a member of ErbB family of receptor tyrosine kinases (RTKs) and plays an important role in resistance to ErbB2 inhibitors. Objective: This study aimed to design a pinostrobin derivative with activity as an ErbB4 inhibitor and to establish a quantitative structure-property relationship (QSPR) of pinostrobin and its derivatives to predict drug clearance. Materials and Methods: In this research, an in silico study was conducted on pinostrobin and its derivatives by predicting the prediction of activity spectra for substances (PASS) with PASS online, followed by molecular docking using the AutoDockTools 4.2.6 program on ErbB4 protein kinase and visualizing the docking results using the Discovery Studio Visualizer software. While the study of OSPR pinostrobin and its derivatives was determined using physicochemical parameters with clearance $\left(\mathrm{CL}_{2}\right)$ using SPSS. Results: From the data obtained, 5-O-2 phenylacetylpinostrobin has a high affinity for ErbB4 protein with a free energy of binding $(\Delta G)-10.37$ $\mathrm{kcal} / \mathrm{mol}$ and an inhibition constant (Ki) of $26.06 \mathrm{nM}$. Conclusion: Probability "to be active" (Pa) 5-O-2phenylacetylpinostrobin of 0.595 for kinase inhibitors and 0.666 for apoptosis agonists, thus becoming candidates for breast cancer drugs. The QSPR model can be used to predict the properties of molecules such as $\mathrm{CL}_{\text {tot }}$ this will be useful in the drug design process. The best QSPR regression equation for pinostrobin and its derivatives is $\log \left(1 / \mathrm{CL}_{\text {tot }}\right)=0.705 \log \mathrm{S}+0.035 \mathrm{MR}+0.375$. This equation can be used as a reference in predicting $\mathrm{CL}_{\text {tot }}$

Key words: 5-O-acylpinostrobin, Molecular docking, PASS, Pharmacokinetic, Physicochemical properties.
\end{abstract}

- Review completed: 21-07-2021

- Accepted Date: 30-07-2021.

DOI : 10.5530/pj.2021.13.147

Article Available online

http://www.phcogj.com/v13/i5

Copyright

(C) 2021 Phcogj.Com. This is an openaccess article distributed under the terms of the Creative Commons Attribution 4.0 International license.

\section{INTRODUCTION}

ErbB4 (HER4) is a member of the epidermal growth factor (EGF)/ErbB family of receptor tyrosine kinases (RTKs) ${ }^{1}$ and other members are EGFR (ErbB1/HER1), ErbB2 (HER2/ Neu), ErbB3 (HER3). ${ }^{2}$ ErbB2 overexpression occurs in about $20 \%$ of breast cancers and is associated with poorer overall survival. ${ }^{3}$ Treatment with ErbB2-targeted inhibitors, trastuzumab, and lapatinib provide considerable clinical benefit in HER2-positive breast cancer patients, but most show resistance to ErbB2-targeted inhibitors ${ }^{4,5}$ due to activation of c-Src tyrosine kinase ${ }^{6}$, ErbB3 upregulation ${ }^{7}$, and ErbB4 activation. ${ }^{8,9}$ ErbB4 activation plays a key role in the survival of cancer cells that have developed resistance to ErbB2 inhibitors. ErbB4 knockdown causes a decrease in AKT phosphorylation and activates the PI3K/AKT pathway in lapatinibresistant cells, thereby triggering apoptosis. ${ }^{9}$ Therefore, it is necessary to develop a new drug that has a better activity and more selective as an ErbB4 inhibitor. ${ }^{9}$

Pinostrobin is a flavanone contained in Boesenbergia pandurata and is a marker compound of the plant. ${ }^{10}$ In recent years, several studies have been conducted on the development of pinostrobin as an anticancer agent such as in silico, in vitro, and in vivo. ${ }^{11-13}$ Although encouraging, the development of pinostrobin for breast cancer is still slow. The breast anticancer activity of pinostrobin is still lower than drugs on the market. So that in this study, an in silico was conducted to determine the activity of pinostrobin and its derivatives as ErbB4 inhibitors.

QSPR is not only used to establish quantitative relationships between structural properties and property parameters of new compounds but provides a better explanation of the factors that influence the pharmacokinetic fate of drugs. ${ }^{14}$ The $\mathrm{CL}_{\text {tot }}$ value of a drug is an important pharmacokinetic parameter because it is directly related to the bioavailability and elimination of the drug and can be used to determine the dosing rate and steady-state concentration. ${ }^{15}$ Therefore, it is important to predict the value of $\mathrm{CL}_{\text {tot }}$ during drug discovery so that compounds with acceptable metabolic stability can be identified and compounds with poor bioavailability can be eliminated. ${ }^{14}$

\section{MATERIALS AND METHODS}

\section{Hardware}

The specification of the computer that is used: Intel $^{\circledR}$ Core $^{\text {ta }}$ i7 8565U@ $1.80 \mathrm{GHz}$ processor (CPU), Nvidia ${ }^{\oplus}$ GeForce MX230 graphics processing unit (GPU), and 8 GB Random Access Memory (RAM) with Windows 10.

\section{Compound Test Preparation}

Pinostrobin compounds and their derivatives are the results of structural modifications by adding 
a substituted acyl group at the position of the benzene ring of the pinostrobin compound as shown in Table 1. The test compounds were made in 2D and 3D models, then optimized by the MMFF94 method on Chem3D 20.0. And then, the structure is translated to SMILES format using Online SMILES Translator (https://cactus.nci.nih.gov/ translate/).

\section{PASS prediction}

To validate compounds as suitable drug candidates, prediction of activity spectra for substances (PASS) (http://www.pharmaexpert.ru/ passonline/) is used to predict the possible pharmacological effects of a compound based on structural information by looking at the $\mathrm{Pa}$ score (probability " to be active") and Pi (probability "to be inactive") by entering the SMILES format. ${ }^{16}$

\section{Molecular docking}

The structure of the ErbB4 kinase target receptor (PDB ID: 3BBT) obtained from the Protein Data Bank (https://www.rcsb.org/) and containing the native ligand lapatinib that is shown in Figure 1.

Molecular docking is done using AutoDockTools 4.2.6 program. Starting with the validation process, the redocking method uses the extracted cocrystal ligand from the receptor as the test ligand and the location of the cocrystal ligand as the binding site. ${ }^{17}$ The validation results are indicated by the Root Mean Square Deviation (RMSD) value. ${ }^{18}$ Center the grid box using a grid box $(40 \times 40 \times 40)$. The binding site coordinates are $\mathrm{x}=-36,287 ; \mathrm{y}=53,585 ; \mathrm{z}=-11962$ with spacing per unit 0.375 angstrom. AutoDockTools 4.2.6 program run with the specified parameters: number generation algorithm 27,000, calculate 2,500,000 times (Medium), population 150, and the implementation of running GA as much as 10 times. Visualization analysis of proteinligand interactions was performed with Discovery Studio Visualizer v.19.1.0.18287 from BIOVIA.

\section{QSPR studies}

The QSPR study of pinostrobin and its derivatives was determined using physicochemical parameters with $\mathrm{CL}_{\text {tot }}$ property. The physicochemical parameters consisted of lipophilic parameters (log $\mathrm{P}$ and $\log \mathrm{S}$ ), electronic parameters $\left(\mathrm{E}_{\text {tot }}, \mathrm{E}_{\mathrm{HOMO}}, \mathrm{E}_{\mathrm{LUMO}}\right)$, and steric parameters (MW and $\mathrm{MR})$. Properties are indicated by $\mathrm{CL}_{\text {tot }}$ or $\log \left(1 / \mathrm{CL}_{\text {tot }}\right)$ obtained from prediction results using pkCSM online (http://biosig.unimelb. edu.au/pkcsm/prediction). Physicochemical parameters such as $\log \mathrm{P}$, MW, and MR were obtained by the DruLiTo program, while the log $\mathrm{S}$ was obtained from the ChemDraw 20.0 program. $\mathrm{E}_{\text {tot }}, \mathrm{E}_{\text {Hомо }}, \mathrm{E}_{\mathrm{LUMO}}$ obtained from Chem3D 20.0. In addition, to determine the QSPR, the SPSS program is used..$^{19-21}$

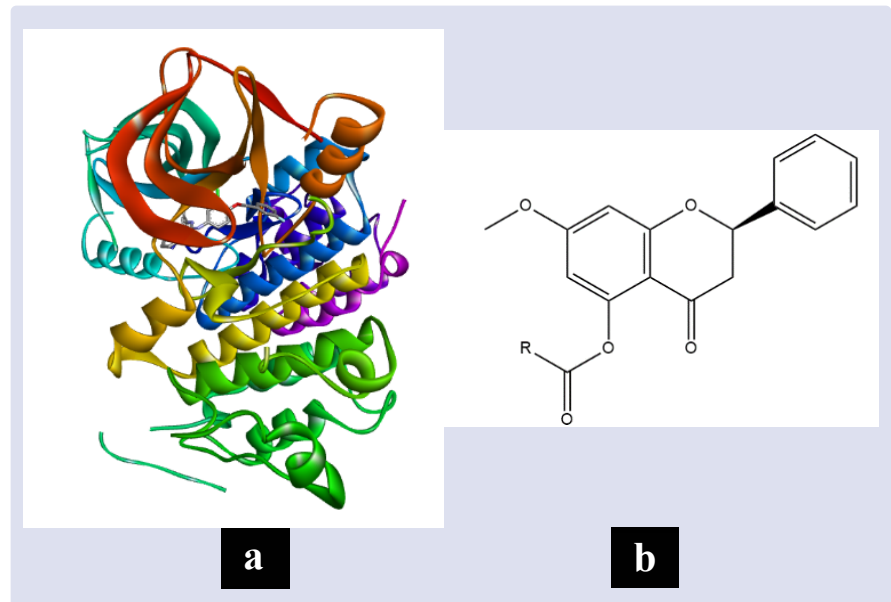

Figure 1: Structure of ErbB4 kinase (a) and pinostrobin derivatives (b).

\section{RESULTS}

\section{PASS prediction}

The prediction results of the $\mathrm{Pa}$ and $\mathrm{Pi}$ scores of pinostrobin derivatives are shown in Table 1.

\section{Molecular docking}

The results of docking validation are indicated by the RMSD value of $1.008 \AA$, so it can be concluded that the docking protocol can be declared valid because the RMSD value is $<2 \AA$. Based on the docking results, all pinostrobin derivatives obtained more negative $\Delta \mathrm{G}$ scores than pinostrobin compounds (Table 2). The more negative the $\Delta \mathrm{G}$ score and the smaller the Ki value, it indicates a very strong complex formed between the ligand and standard. While the visualization of ligands and comparisons can be seen in Figure 2 and Table 3.

\section{QSPR studies}

The physicochemical parameter values of the substituted substituents can be seen in Table 4. While the linear regression equation is shown in Table 5.

\section{DISCUSSION}

Modification structure can increase the potency and selectivity of compound. In designing a potent and selective compound, several methods can be used, one of the methods is in silico. The advantage of using this method is to optimize activity, geometry, and reactivity before the compound is synthesized experimentally. This can reduce the synthesis step of a compound that requires time and expensive costs, but the resulting compound does not have the activity as expected. In developing pinostrobin as a new breast cancer drug, to increase the anticancer activity of the breast, modification of the structure of pinostrobin was carried out by adding an acyl group. The selection of these substituents is based on changes in lipophilic, electronic, and steric properties. In this study, several initial stages in the development of new drugs have been carried out by the principles of rational drug discovery and development.

The $\mathrm{Pa}$ value is the possibility of a compound being active in carrying out biological activities in laboratory experiments, while the Pi value is the opposite. If a compound has a value of $\mathrm{Pa}>\mathrm{Pi}$, then the compound has the potential to have this activity. In Table 1, pinostrobin has strong potential on a laboratory scale because the $\mathrm{Pa}$ value $>0.7$, while its derivatives have moderate activity because the $\mathrm{Pa}$ value is $0.5<\mathrm{Pa}<0.7$. $^{22}$ Because these compounds have not been studied on a laboratory scale, further research is needed.

Molecular docking is computational modeling research that aims to detect the interaction of ligands with receptors. Bond energy is influenced by Gibbs free energy $(\Delta G)$, a reaction that takes place spontaneously will have a negative Gibbs free energy at temperature and constant temperature. Bond energy is affected by several components which are expressed by the following equation: $\llbracket \Delta G \rrbracket \_$Hatanic $=\llbracket \Delta G \rrbracket$ _Gauss $+\llbracket \Delta G \rrbracket \_$Repulsion $+\llbracket \Delta G \rrbracket \_$HBond $+\llbracket \Delta G \rrbracket$ _Hydrophobic + $\overline{[} \Delta \mathrm{G} \rrbracket$ _Torsion. The more energy components contribute, the smaller the "G" value (becomes negative), the bond impact will be stronger and cause high affinity. ${ }^{23}$ From the results of the study [Table 2], it is known that 5-O-2-phenylacetylpinostrobin has a stronger inhibitory activity than lapatinib, marked by $\Delta \mathrm{G}$ of $-10.37 \mathrm{kcal} / \mathrm{mol}$ and lapatinib -10.30 $\mathrm{kcal} / \mathrm{mol}$. So that $\Delta \mathrm{G}$ is very negative, it can be ascertained that the reaction will be proceed spontaneously and lead to high affinity. The $\mathrm{Ki}$ values of these compounds are 26.06 and $28.11 \mathrm{nM}$. The Ki value is not only used to indicate the affinity of a ligand, it is also used to predict in vitro analysis processes. In this study, the presence of the 2-phenylacetyl substituent had a significant effect on the affinity of the pinostrobin derivative for the ErbB4 kinase receptor target. Thus, 


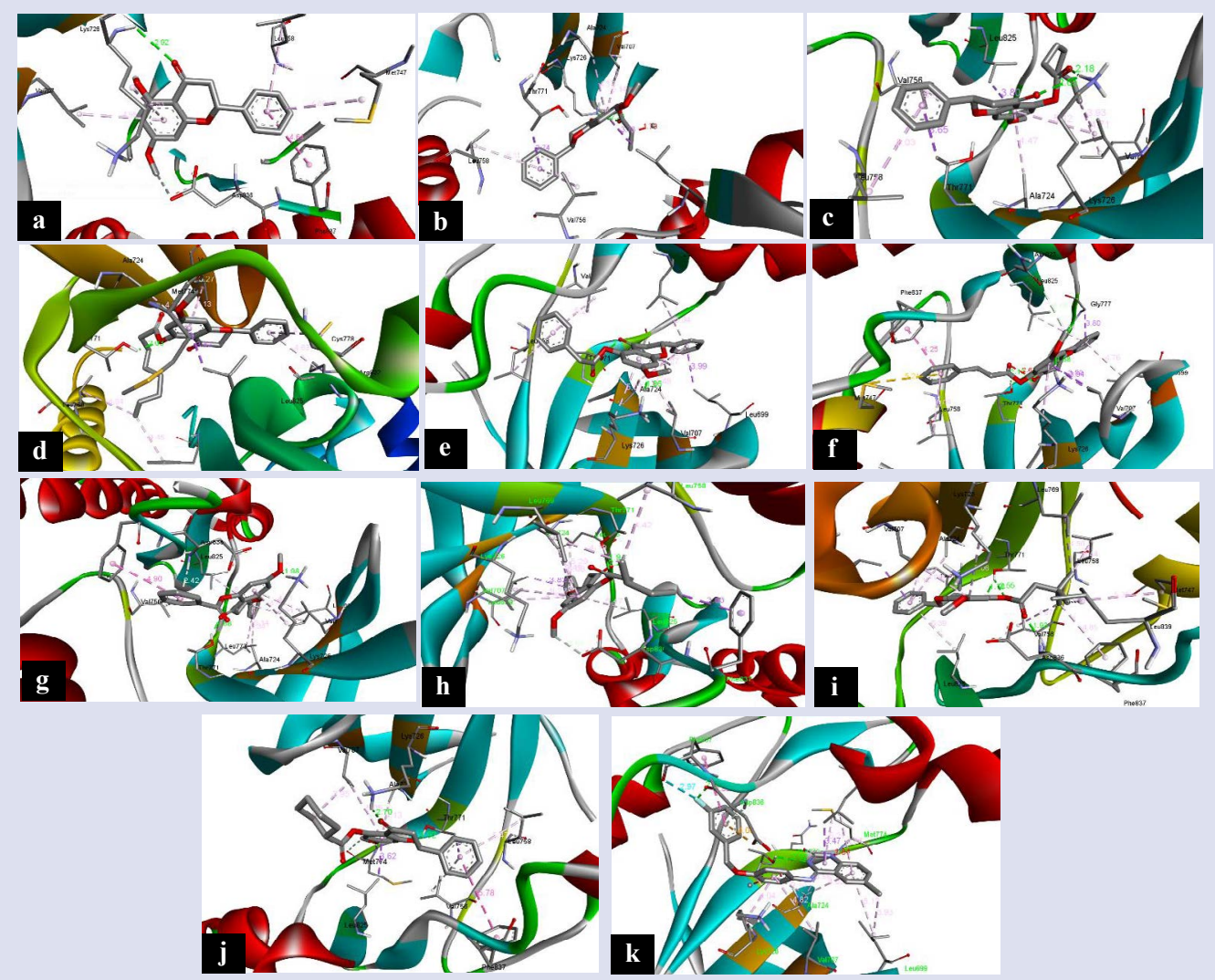

Figure 2: Visualization of pinostrobin (a), 5-O-2-cloropropionylpinostrobin (b), 5-O-heptanoylpinostrobin (c), 5-O-octanoylpinostrobin (d), 5-O-2-phenylacetylpinostrobin (e), 5-O-3-phenylpropionylpinostrobin (f), 5-O-benzoylpinostrobin (g), 5-O-3-methylpentanoylpinostrobin (h), 5-O-3,3-dimethylbutyrylpinostrobin (i), 5-O-cyclohexanecarbonylpinostrobin (j), lapatinib (k) bound to the active sites of ErbB4 kinase.

Table 1: The pinostrobin derivatives test compound and PASS result.

\begin{tabular}{|c|c|c|c|c|c|c|}
\hline \multirow{2}{*}{ Code } & \multirow{2}{*}{$\mathbf{R}$} & \multirow{2}{*}{ Compound Name } & \multicolumn{2}{|c|}{ Kinase inhibitor } & \multicolumn{2}{|c|}{ Apoptosis agonist } \\
\hline & & & $\mathrm{Pa}$ & $\mathrm{Pi}$ & $\mathrm{Pa}$ & $\mathrm{Pi}$ \\
\hline $\mathrm{P}$ & $\mathrm{H}$ & Pinostrobin & 0.805 & 0.005 & 0.730 & 0.012 \\
\hline P1 & $\mathrm{Cl}-\mathrm{CH}_{2}-\mathrm{CH}_{2}$ & 5-O-2-cloropropionylpinostrobin & 0.566 & 0.024 & 0.475 & 0.045 \\
\hline P2 & $\mathrm{C}_{6} \mathrm{H}_{13}$ & 5-O-heptanoylpinostrobin & 0.546 & 0.027 & 0.666 & 0.019 \\
\hline P3 & $\mathrm{C}_{7} \mathrm{H}_{15}$ & 5-O-octanoylpinostrobin & 0.546 & 0.027 & 0.584 & 0.025 \\
\hline $\mathrm{P} 4$ & $\mathrm{C}_{6} \mathrm{H}_{5}-\mathrm{CH}_{2}$ & 5-O-2-phenylacetylpinostrobin & 0.595 & 0.021 & 0.666 & 0.019 \\
\hline P5 & $\mathrm{C}_{6} \mathrm{H}_{5}-\mathrm{CH}_{2}-\mathrm{CH}_{2}$ & 5-O-3-phenylpropionylpinostrobin & 0.544 & 0.027 & 0.593 & 0.027 \\
\hline P6 & $\mathrm{C}_{6} \mathrm{H}_{5}$ & 5-O-benzoylpinostrobin & 0.667 & 0.015 & 0.672 & 0.018 \\
\hline P7 & $\mathrm{CH}_{3}-\mathrm{CH}_{2}-\mathrm{CH}\left(\mathrm{CH}_{3}\right)-\mathrm{CH}_{2}$ & 5-O-3-methylpentanoylpinostrobin & 0.544 & 0.035 & 0.603 & 0.026 \\
\hline P8 & $\left(\mathrm{CH}_{3}\right)_{3} \mathrm{CH}-\mathrm{CH}_{2}$ & 5-O-3,3-dimethylbutyrylpinostrobin & 0.546 & 0.027 & 0.594 & 0.027 \\
\hline P9 & $\mathrm{C}_{4} \mathrm{H}_{3} \mathrm{CO}$ & 5-O-cyclohexanecarbonylpinostrobin & 0.650 & 0.016 & 0.614 & 0.025 \\
\hline
\end{tabular}

Table 2: Molecular docking binding affinity of pinostrobin derivatives, ranked by the lowest free energy of binding $(\Delta \mathrm{G})$ and inhibition constant (Ki).

\begin{tabular}{|c|c|c|c|}
\hline Code & Compound name & $\Delta \mathrm{G}(\mathrm{kcal} / \mathrm{mol})$ & Ki (nM) \\
\hline $\mathrm{P} 4$ & 5-O-2-phenylacetylpinostrobin & -10.37 & 26.06 \\
\hline $\mathrm{L}$ & Lapatinib & -10.30 & 28.11 \\
\hline P5 & 5-O-3-phenylpropionylpinostrobin & -10.23 & 31.93 \\
\hline P3 & 5-O-octanoylpinostrobin & -9.85 & 60.67 \\
\hline P7 & 5-O-3-methylpentanoylpinostrobin & -9.53 & 102.69 \\
\hline $\mathrm{P} 2$ & 5-O-heptanoylpinostrobin & -9.39 & 131.65 \\
\hline P8 & 5-O-3,3-dimethylbutyrylpinostrobin & -9.37 & 134.77 \\
\hline P6 & 5-O-benzoylpinostrobin & -9.14 & 200.71 \\
\hline P9 & 5-O-cyclohexanecarbonylpinostrobin & -9.08 & 219.20 \\
\hline P1 & 5-O-2-cloropropionylpinostrobin & -8.60 & 495.35 \\
\hline $\mathrm{P}$ & Pinostrobin & -7.18 & 5470 \\
\hline
\end{tabular}


Praditapuspa EN, et al.: In Silico Analysis of Pinostrobin Derivatives from Boesenbergia pandurata on ErbB4 Kinase Target and QSPR Linear Models to Predict Drug Clearance for Searching Anti-Breast Cancer Drug Candidates

Table 3: Interaction of ligands and amino acid residues. The hydrogen bond distance is given, the hydrophobic interactions are indicated by a tick $(\checkmark)$.

$\begin{array}{ccccccccccccccc}\text { Code } & \text { Leu699 } & \text { Val707 } & \text { Ala724 } & \text { Lys726 } & \text { Met747 } & \text { Val756 } & \text { Leu758 } & \text { Thr771 } & \text { Gln772 } & \text { Leu773 } & \text { Met774 Leu825 } & \text { Asp836 Phe837 } \\ \text { L } & \checkmark & \checkmark & \checkmark & \checkmark & - & - & - & 2.92 \AA & \checkmark & - & \checkmark & \checkmark & \checkmark \\ \text { P } & - & \checkmark & - & 2.92 \AA & \checkmark & - & \checkmark & - & - & - & - & - & \checkmark \\ \text { P1 } & - & \checkmark & \checkmark & 2.29 \AA & - & \checkmark & \checkmark & - & - & - & - & \checkmark & - \\ \text { P2 } & \checkmark & \checkmark & \checkmark & 2.18 \AA & - & \checkmark & \checkmark & \checkmark & - & - & - & \checkmark & - \\ \text { P3 } & - & \checkmark & \checkmark & - & - & - & \checkmark & 2.03 \AA & - & - & \checkmark & \checkmark & - \\ \text { P4 } & - & \checkmark & \checkmark & 1.86 \AA & - & - & \checkmark & 1.75 \AA & - & \checkmark & - & \checkmark & - \\ \text { P5 } & \checkmark & \checkmark & - & 1.88 \AA & - & - & \checkmark & 2.09 \AA & - & - & - & \checkmark & - \\ \text { P6 } & \checkmark & \checkmark & \checkmark & 1.98 \AA & - & \checkmark & - & 1.68 \AA & - & \checkmark & - & \checkmark & - \\ \text { P7 } & \checkmark & \checkmark & \checkmark & \checkmark & - & - & \checkmark & 1.94 \AA & - & - & - & \checkmark & - \\ \text { P8 } & \checkmark & \checkmark & \checkmark & \checkmark & - & \checkmark & \checkmark & 1.78 \AA & & \checkmark & \checkmark \\ \text { P9 } & - & \checkmark & \checkmark & 2.70 \AA & - & \checkmark & \checkmark & 1.92 \AA & - & - & \checkmark & \checkmark & 1.93 \AA & \checkmark\end{array}$

L: Lapatinib, P: Pinostrobin, P1:5-O-2-cloropropionylpinostrobin, P2:5-O-heptanoylpinostrobin, P3:5-O-octanoylpinostrobin, P4:5-O-2-phenylacetylpinostrobin P5: 5-O-3-phenylpropionylpinostrobin, P6: 5-O-benzoylpinostrobin, P7: 5-O-3-methylpentanoylpinostrobin, P8: 5-O-3,3-dimethylbutyrylpinostrobin, P9: 5-O-cyclohexanecarbonylpinostrobin.

Table 4: Physicochemical parameters and $\mathrm{CL}_{\text {tot }}$.

\begin{tabular}{|c|c|c|c|c|c|c|c|c|c|}
\hline Code & $\log P$ & $\log S$ & $E_{\text {tot }}$ & $\mathrm{E}_{\text {номо }}$ & $\mathrm{E}_{\text {LUMO }}$ & MW & MR & $\mathrm{CL}_{\text {tot }}$ & $\log \left(1 / \mathrm{CL}_{\text {tot }}\right)$ \\
\hline $\mathrm{P}$ & 1.825 & -3.433 & 46.2483 & -11.207 & -3.449 & 255.98 & 81.96 & 0.136 & 0.8664 \\
\hline $\mathrm{P} 1$ & 2.537 & -4.501 & 75.4066 & -10.968 & -3.569 & 360.08 & 100.81 & 0.358 & 0.4461 \\
\hline P2 & 4.545 & -5.824 & 54.9488 & -11.306 & -3.573 & 382.18 & 108.07 & 1.258 & -0.0996 \\
\hline P3 & 5.114 & -6.242 & 56.0354 & -11.308 & -3.572 & 396.19 & 110.98 & 1.283 & -0.1082 \\
\hline $\mathrm{P} 4$ & 3.349 & -5.646 & 91.0089 & -11.295 & -3.519 & 388.13 & 120.26 & 0.238 & 0.6234 \\
\hline P5 & 3.729 & -5.814 & 72.3604 & -11.313 & -3.542 & 402.15 & 125.12 & 0.312 & 0.5058 \\
\hline P6 & 3.078 & -5.813 & 109.8573 & -11.381 & -3.720 & 374.12 & 115.71 & 0.471 & 0.3269 \\
\hline P7 & 3.915 & -5.214 & 60.5646 & -11.315 & -3.592 & 368.16 & 107.87 & 0.348 & 0.4584 \\
\hline P8 & 3.952 & -4.973 & 69.2658 & -11.301 & -3.520 & 368.16 & 109.65 & 0.164 & 0.7851 \\
\hline P9 & 3.929 & -5.690 & 70.8073 & -11.370 & -3.612 & 390.16 & 107.23 & 1.038 & -0.0162 \\
\hline
\end{tabular}

Log P: Partition coefficient, Log S: Solubility, $\mathrm{E}_{\text {tot }}$ : Minimum energy, $\mathrm{E}_{\text {номо }}$ : Highest occupied molecular orbital, $\mathrm{E}_{\text {Lumo: }}$ Lowest unoccupied molecular orbital, MW: Molecular weight, $\mathrm{MR}$ : Molar refractivity, $\mathrm{CL}_{\text {tot }}:$ Clearance total.

Table 5: Linear regression equation.

\begin{tabular}{|c|c|c|c|c|c|c|}
\hline No. & Linear regression equation & $\mathrm{n}$ & $r$ & SE & $\mathbf{F}$ & Sig. \\
\hline \multicolumn{7}{|c|}{ One Physicochemical Parameter } \\
\hline 1 & $\log \left(1 / \mathrm{CL}_{\text {tot }}\right)=-0.258 \log \mathrm{P}-1.309$ & 10 & 0.699 & 0.2669 & 7.640 & 0.025 \\
\hline 2 & $\log \left(1 / \mathrm{CL}_{\text {tot }}\right)=0.298 \log \mathrm{S}+1.960$ & 10 & 0.702 & 0.2659 & 7.759 & 0.024 \\
\hline 3 & $\log \left(1 / \mathrm{CL}_{\text {tot }}\right)=0.002 \mathrm{E}_{\text {tot }}+0.271$ & 10 & 0.081 & 0.3720 & 0.053 & 0.824 \\
\hline 4 & $\log \left(1 / \mathrm{CL}_{\text {tot }}\right)=0.832 \mathrm{E}_{\text {номо }}+9.765$ & 10 & 0.279 & 0.3584 & 0.676 & 0.435 \\
\hline 5 & $\log \left(1 / \mathrm{CL}_{\text {tot }}\right)=2.666 \mathrm{E}_{\text {LUMO }}+9.886$ & 10 & 0.537 & 0.3149 & 3.237 & 0.110 \\
\hline 6 & $\log \left(1 / \mathrm{CL}_{\text {tot }}\right)=-0.005 \mathrm{MW}+2.148$ & 10 & 0.570 & 0.3066 & 3.849 & 0.085 \\
\hline 7 & $\log \left(1 / \mathrm{CL}_{\text {tot }}\right)=-0.007 \mathrm{MR}+1.163$ & 10 & 0.240 & 0.3622 & 0.490 & 0.504 \\
\hline \multicolumn{7}{|c|}{ Two Physicochemical Parameter } \\
\hline 8 & $\log \left(1 / \mathrm{CL}_{\text {tot }}\right)=-0.261 \log \mathrm{P}-0.001 \mathrm{E}_{\text {tot }}+1.373$ & 10 & 0.700 & 0.2849 & 3.365 & 0.095 \\
\hline 9 & $\log \left(1 / \mathrm{CL}_{\text {tot }}\right)=-0.28 \log \mathrm{P}-0.34 \mathrm{E}_{\text {номо }}+2.444$ & 10 & 0.706 & 0.2827 & 3.472 & 0.090 \\
\hline 10 & $\log \left(1 / \mathrm{CL}_{\text {tot }}\right)=-0.222 \log \mathrm{P}+1.90 \mathrm{E}_{\mathrm{LUMO}}+7.956$ & 10 & 0.791 & 0.2442 & 5.840 & 0.032 \\
\hline 11 & $\log \left(1 / \mathrm{CL}_{\text {tot }}\right)=-0.228 \log \mathrm{P}-0.001 \mathrm{MW}+1.540$ & 10 & 0.730 & 0.2838 & 3.414 & 0.092 \\
\hline 12 & $\log \left(1 / \mathrm{CL}_{\text {tot }}\right)=-0.296 \log \mathrm{P}+0.006 \mathrm{MR}+0.828$ & 10 & 0.717 & 0.2782 & 3.698 & 0.080 \\
\hline 13 & $\log \left(1 / \mathrm{CL}_{\text {tot }}\right)=0.354 \log \mathrm{S}+0.007 \mathrm{E}_{\text {tot }}+1.759$ & 10 & 0.785 & 0.2473 & 5.605 & 0.035 \\
\hline 14 & $\log \left(1 / \mathrm{CL}_{\text {tot }}\right)=0.352 \log \mathrm{S}-0.644 \mathrm{E}_{\mathrm{HOMO}}-5.014$ & 10 & 0.723 & 0.2757 & 3.829 & 0.075 \\
\hline 15 & $\log \left(1 / \mathrm{CL}_{\text {tot }}\right)=0.249 \log \mathrm{S}+0.095 \mathrm{E}_{\mathrm{LUMO}}+5.181$ & 10 & 0.720 & 0.2770 & 3.761 & 0.078 \\
\hline 16 & $\log \left(1 / \mathrm{CL}_{\text {tot }}\right)=0.471 \log \mathrm{S}+0.004 \mathrm{MW}+1.494$ & 10 & 0.724 & 0.2750 & 3.865 & 0.074 \\
\hline 17 & $\log \left(1 / \mathrm{CL}_{\text {tot }}\right)=0.705 \log \mathrm{S}+0.035 \mathrm{MR}+0.375$ & 10 & 0.944 & 0.1318 & 28.566 & 0.000 \\
\hline
\end{tabular}


pinostrobin derivatives have greater activity against target receptors than pinostrobin.

The main objective of the QSPR study is to design drugs by modifying the chemical structure of active drugs pharmacodynamically. The main advantage of QSPR lies that once the association is confirmed with a sufficient level of statistical confidence, it can be a valuable aid in the prognosis of the behavior of new molecules, even before the synthesis is done. ${ }^{24}$ The results of statistical analysis [Table 5], proposed the best equation: $\log \left(1 / \mathrm{CL}_{\text {tot }}\right)=0.705 \log \mathrm{S}+0.035 \mathrm{MR}+0.375(\mathrm{n}=10$; sig. $=0.000 ; \mathrm{r}=0.944 ; \mathrm{F}=28.566$; and $\mathrm{SE}=0.1318$ ). The equation was chosen because it has the largest correlation coefficient $(\mathrm{r}=0.944)$ and the smallest significance that is 0.000 . From the selected equation, it can be explained that the physicochemical properties affect $\mathrm{CL}_{\text {tot }}$ pinostrobin and its derivatives are lipophilic $(\log S)$ and steric (MR) properties. This equation can be used as a reference in predicting the $\mathrm{CL}_{\text {tot }}$ of pinostrobin-derived compounds with different substituents by including the $\log \mathrm{S}$ and MR parameters in the equation.

\section{CONCLUSION}

Based on the research, 5-O-2-phenylacetylpinostrobin has a high affinity for ErbB4 protein with $\Delta \mathrm{G}-10.37 \mathrm{kcal} / \mathrm{mol}$ and $\mathrm{Ki} 26.06 \mathrm{nM}$ and Pa score of 5-O-2-phenylacetylpinostrobin of 0.595 for kinase inhibitors and 0.666 for apoptosis agonists and therefore it becomes candidate for breast cancer drugs. The statistical results and the application of the developed model to the test set show that the QSPR model can be used to predict molecular properties such as $\mathrm{CL}_{\text {tot }}$, so it will be useful in the drug development process. The best QSPR regression equation of pinostrobin and its derivatives is $\log \left(1 / \mathrm{CL}_{\text {tot }}\right)=0.705 \log \mathrm{S}+0.035$ $\mathrm{MR}+0.375$.

\section{REFERENCES}

1. Carpenter G. ErbB-4: mechanism of action and biology. Exp Cell Res. 2003;284:66-77.

2. Holbro T, Hynes NE. ErbB receptors: directing key signaling networks throughout life. Annu Rev Pharmacol Toxicol. 2004;44:195-217.

3. Slamon DJ, Clark GM, Wong SG, Levin WJ, Ullrich A, McGuire WL. Human breast cancer: correlation of relapse and survival with amplification of the HER-2/neu oncogene. Sci. 1987;235:177- 182.

4. Piccart M. Circumventing de novo and acquired resistance to trastuzumab: new hope for the care of ErbB2-positive breast cancer. Clinical Breast Cancer. 2008;8:S100-S113.

5. Kaufman B, Trudeau M, Awada A, Blackwell K, Bachelot T, Salazar V, et al. Lapatinib monotherapy in patients with HER2-overexpressing relapsed or refractory inflammatory breast cancer: final results and survival of the expanded HER2C cohort in EGF103009, a phase II study. Lancet Oncol. 2009;10:581-588.

6. Zhang S, Huang WC, Li P, Guo H, Poh SB, Brady SW, et al. Combating trastuzumab resistance by targeting SRC, a common node downstream of multiple resistance pathways. Nature Med. 2011;17:461-469.

7. Garrett JT, Olivares MG, Rinehart C, Granjalngram ND, Sanchez $\mathrm{V}$, Chakrabarty $\mathrm{A}$, et al. Transcriptional and posttranslational upregulation of HER3 (ErbB3) compensates for inhibition of the HER2 tyrosine kinase. Proc Natl Acad Sci. 2011;108:5021-5026.
8. Ding J, Yao Y, Huang G, Wang X, Yi J, Zhang N, et al. Targeting the EphB4 receptor tyrosine kinase sensitizes HER2-positive breast cancer cells to Lapatinib. Cancer Lett. 2020;475:53-64.

9. Canfield K, Li J, Wilkins OM, Morrison MM, Ung M, Wells W, et al. Receptor tyrosine kinase ERBB4 mediates acquired resistance to ERBB2 inhibitors in breast cancer cells. Cell Cycle. 2015;14:648-655.

10. Tan BC, Tan SK, Wong SM, Ata N, Rahman NA, Khalid N. Distribution of flavonoids and cyclohexenyl chalcone derivatives in conventional propagated and in vitro-derived field-grown Boesenbergia rotunda (L.) Mansf. Evid Based Complement Alternat Med. 2015;2015:451870.

11. Atun $S$, Arianingrum R. Anticancer activity of bioactive compounds from Kaempferia rotunda rhizome against human breast cancer. Int $J$ Pharmacogn Phytochem Res. 2015;7:262-9.

12. Sukardiman, Charisma D, Plumeriastuti H, Arifianti L. Anticancer effect of pinostrobin from (Kaempferia pandurata Roxb) in Benzo(a) pyrene induced fibrosaroma in mice. E J Planta Husada. 2014;2:44-46.

13. Pratama MRF, Poerwono H, Siswandono S. Design and molecular docking of novel 5-O-Benzoylpinostrobin derivatives as anti-breast cancer. Thai J Pharm Sci. 2020;43:201-212.

14. Paul Y, Dhake AS, Parle $M$, Singh B. Quantitative Structure Pharmacokinetic Relationship Studies for Drug Clearance of Quinolone Drugs. Research J Pharm and Tech. 2008;1:106-111.

15. Toutain PL, Melou AB. Plasma Clearance. J. Vet. Pharmacol. Ther. 2004;27: 415-425.

16. Filimonov DA, Lagunin AA, Gloriozova TA, Rudik AV, Druzhilovskii DS, Pogodin PV, et al. Prediction of the biological activity spectra of organic compounds using the PASS online web resource. Chemistry of Heterocyclic Compounds. 2014;50(3):444-57.

17. Megantara S, Iwo MI, Levita J, Ibrahim S. Determination of ligand position in aspartic proteases by correlating tanimoto coefficient and binding affinity with root mean square deviation. J Appl Pharm Sci. 2016;6:125-9.

18. Pagadala NS, Syed K, Tuszynski J. Software for molecular docking: A review. Biophys Rev. 2017;9:91-102.

19. Pires DE, Blundell TL, Ascher DB. pkCSM: predicting smallmolecule pharmacokinetic and toxicity properties using graph-based signatures. J Med Chem. 2015;58: 4066-4072.

20. Hardjono S, Siswandono, Purwanto, Darmanto W. Quantitative Structure-Cytotoxic Activity Relationship 1-(Benzoyloxy)urea and Its Derivative. Current Drug Discovery Technology. 2016;13:101-108.

21. Siswandono RW, Suryadi A, Widiandani T, Prismawan D. Molecular Modeling, Synthesis, and QSAR of 5-O-Acylpinostrobin Derivatives as Promising Analgesic Agent. Rasayan J. Chem 2020;13:2559-2568.

22. Chelliah DA. Biological activity prediction of an ethno medicinal plant Cinnamomum camphora through bio-informatics. Ethnobotanical leaflets 2008;12:181-90.

23. Kharisma VD, Septiadi L, Syafrudin S. Prediction of novel bioactive compound from zingiber officinale as non-nucleoside reverse transcriptase inhibitors (NNRTIs) of HIV-1 through computational study. Bioinformatics and Biomedical Research Journal 2018;1:49-55.

24. Boobis A, Gundert-Remy U, Kremers P, Macheras P, Pelkonen O. In silico prediction of ADME and pharmacokinetics: Report of an expert meeting organised by COST B15. Eur J Pharm Sci. 2002;17:183-193. 


\section{GRAPHICAL ABSTRACT}
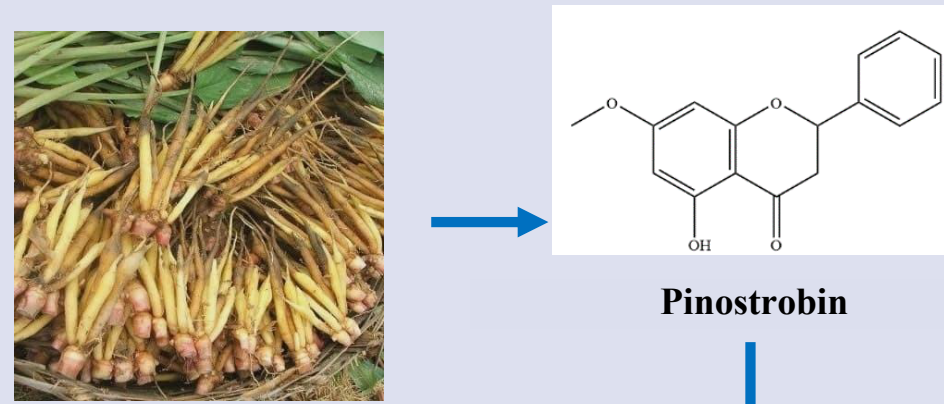

Pinostrobin

Boesenbergia pandurata<smiles>COc1cc(OC(=O)F)c2c(c1)O[C@@H](c1ccccc1)CC2=O</smiles>

Pinostrobin derivatives

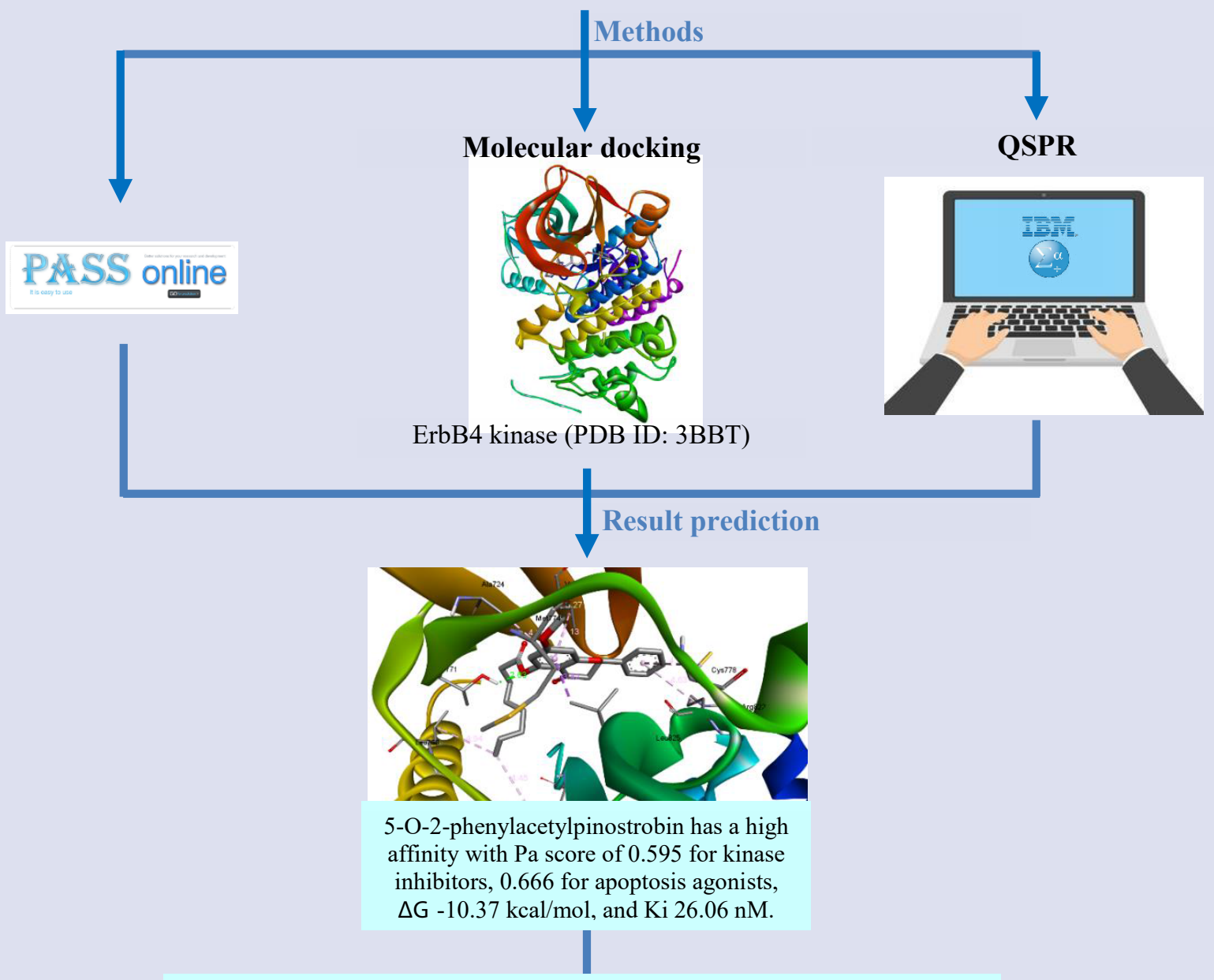

The best QSPR regression equation of pinostrobin and its derivatives is:

$\log \left(1 / \mathrm{CL}_{\text {tot }}\right)=0.705 \log \mathrm{S}+0.035 \mathrm{MR}+0.375$. 


\section{ABOUT AUTHORS}
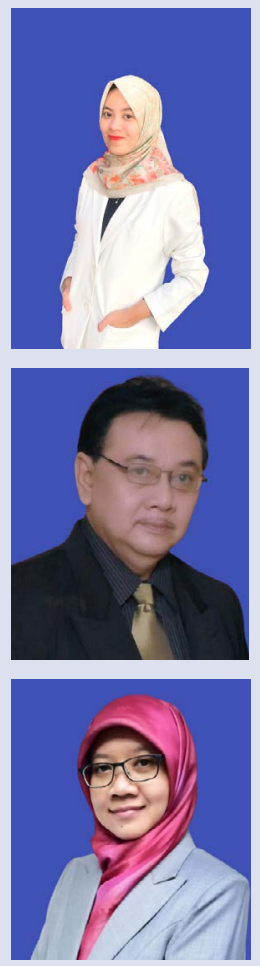

Ersanda Nurma Praditapuspa is a master student at Faculty of Pharmacy, Airlangga University. She obtained her bachelor degree in Pharmacy at Faculty of Medicine, Hang Tuah University. Her research is focuses on drug discovery for anti-breast cancer drugs from bioactive natural products.

Siswandono is a professor from the Department of Pharmaceutical Sciences, Faculty of Pharmacy, Airlangga University. He obtained her bachelor's degree in Pharmacy at the Faculty of Pharmacy, Airlangga University. He was further pursued his Master's and Doctoral degree at the Faculty of Pharmacy, Airlangga University. He acquired a Professor with expertise in the fields of Medicinal Chemistry. His research is focused on drug design and development from synthetic compound or bioactive natural products especially for anticancer and CNS depressant agents.

Tri Widiandani is a lecturer at Faculty of Pharmacy, Airlangga University. She obtained her bachelor degree in Pharmacy at Faculty of Pharmacy, Airlangga University. She was further persued her Specialist of Hospital Pharmacy and Doctoral degree at Faculty of Pharmacy, Airlangga University. Her main courses is Medicinal Chemistry, Physical Chemistry. Her research is focuses on virtual modeling, synthesis of biologically active compounds especially for cancer targeted.

Cite this article: Praditapuspa EN, Siswandono, Widiandani T. In Silico Analysis of Pinostrobin Derivatives from Boesenbergia pandurata on ErbB4 Kinase Target and OSPR Linear Models to Predict Drug Clearance for Searching Anti-Breast Cancer Drug Candidates. Pharmacogn J. 2021;13(5): 1143-1149. 